\title{
Stability of cefoselis sulfate in aqueous solutions
}

\author{
Przemysław Zalewski • Judyta Cielecka-Piontek • \\ Anna Jelińska
}

Received: 13 August 2012/ Accepted: 19 November 2012/Published online: 6 December 2012 (C) The Author(s) 2012. This article is published with open access at Springerlink.com

\begin{abstract}
The influence of $\mathrm{pH}$ on the stability of cefoselis sulfate was investigated in the $\mathrm{pH}$ range $0.44-13.00$. The degradation of cefoselis sulfate in aqueous solutions was a pseudo-first order reaction. General acid-base hydrolysis of cefoselis sulfate was observed in phosphate and acetate buffers. In solutions of hydrochloric acid, sodium hydroxide and borate buffer, $\mathrm{k}_{\mathrm{obs}}=\mathrm{k}_{\mathrm{pH}}$ because only specific acidbase catalysis occurred. Specific acid-base catalysis of cefoselis sulfate involved such reactions as the hydrolysis of protonated cefoselis sulfate molecules $\left(\mathrm{k}_{1}\right)$, hydrolysis of cefoselis sulfate zwitter ions $\left(\mathrm{k}_{2}\right)$ and hydrolysis of cefoselis sulfate monoanions $\left(\mathrm{k}_{3}\right)$ under the influence of water. The total reaction rate was equal to the sum of partial reactions: $\mathrm{k}_{\mathrm{pH}}=\mathrm{k}_{1} \cdot \mathrm{F}_{1}+\mathrm{k}_{2} \cdot \mathrm{F}_{2}+\mathrm{k}_{3} \cdot \mathrm{F}_{3}$ where: $\mathrm{k}_{1}, \mathrm{k}_{2}$ and $\mathrm{k}_{3}$ were the catalytic rate constants calculated as the mean values of $\mathrm{k}_{\mathrm{pH}}$ at $\mathrm{pH} 1.89-3.10$, 4.01-6.16 and at $\mathrm{pH}$ above 11.24. $\mathrm{F}_{1}, \mathrm{~F}_{2}$ and $\mathrm{F}_{3}$ were the molar concentration fractions of the cefoselis sulfate.
\end{abstract}

Keywords Cefoselis sulfate $\cdot$ HPLC $\cdot$ Stability in aqueous solutions

\section{Introduction}

The class of cephalosporins came into being in 1954. Since the isolation of the first cephalosporin, they have been increasingly applied in the treatment of various types of infections. At the moment, there are over twenty cephalosporin antibiotics available commercially.

As the antibacterial activity of cephalosporins is connected with their resistance to alkaline hydrolysis, their therapeutic effect depends on the stability of the

P. Zalewski $(\bowtie) \cdot$ J. Cielecka-Piontek · A. Jelińska

Department of Pharmaceutical Chemistry, Faculty of Pharmacy, Poznan University of Medical Sciences, Grunwaldzka 6, 60-780 Poznań, Poland

e-mail: pzalewski@ump.edu.pl 
Fig. 1 The chemical structure of cefoselis sulfate<smiles>CO/N=C(\C(=O)N[C@H]1C(=O)N2C(C(=O)[O-])=C(C[n+]3ccc(N)n3CCO)CS[C@H]12)c1csc(N)n1</smiles>

$\beta$-lactam moiety, which is often related to the substituent at position three [1-3] (Fig. 1).

In a molecule of cephalosporin, the constituent that is the most prone to degradation is the $\beta$-lactam moiety. Any structural modifications aimed at greater alkaline stability usually result in enhanced vulnerability to degradation in an acidic environment. In principle, antibiotics are expected to be stable at physiological and acidic $\mathrm{pH}$, especially when designed for oral administration [1-3]. With a view to create acid-stable antibiotics, cephalosporins are currently the main target of research into new anti-infection drugs [1]. It has been found that cephalosporins are vulnerable to degradation in aqueous solutions [4-8] and in the solid state [9-15].

Cefoselis sulfate (Fig. 1) is a novel, parenteral, fourth-generation cephalosporin. It has a broad spectrum of antibacterial activity against Gram-positive and Gramnegative bacteria, including Pseudomonas aeruginosa [16-18]. Cefoselis sulfate contains a 3-non-acetoxy group at position C3, which determines its antibacterial activity against methicillin-resistant Staphylococcus aureus. This group is probably responsible for a greater stability of cephalosporins in acidic than in alkaline media and a wide plateau region at neutral $\mathrm{pH}$ [1].

The aim of this work was to evaluate the stability of cefoselis sulfate at a wide $\mathrm{pH}$ range and to determine the $\mathrm{pH}$ range at which it is the most stable. An HPLC method described previously was used to determine acid-base catalysis of cefoselis sulfate [19].

\section{Experimental procedure}

Chemicals, reagents, and solutions

Cefoselis sulfate was obtained from Xingcheng Chempharm Co., Ltd. Taizhou, Zhejiang, China. It is a white or light yellow crystalline powder containing $99.5 \%$ cefoselis sulfate, $0.1 \%$ related substances and complies with the Chinese Pharmacopoeia 2005 regulations.

All other chemicals and solvents were obtained from Merck KGaA (Germany) and were of analytical grade. High quality pure water was prepared by using the Millipore purification system (Millipore, Molsheim, France, model Exil SA 67120).

\section{Instrumentation}

Chromatographic separation and quantitative determination of cefoselis sulfate were conducted by using a high-performance liquid chromatograph equipped with an LC-6A pump (Shimadzu), a UV-Vis (SPD-6AV) detector (Shimadzu) and a 
Rheodyne with a $50 \mu \mathrm{L}$ loop. As the stationary phase, a LiChrospher RP-18 column, $5 \mu \mathrm{m}$ particle size, $250 \times 4 \mathrm{~mm}$ (Merck, Darmstadt, Germany) was used. The mobile phase consisted of 5 volumes of acetonitrile and 95 volumes of ammonium acetate, $12 \mathrm{mmol} \mathrm{L}^{-1}$, the $\mathrm{pH}$ of the mobile phase was 7.15. The flow rate of the mobile phase was $1.0 \mathrm{~mL} \mathrm{m^{-1 }}$. The wavelength of the detector was set at $260 \mathrm{~nm}$. The HPLC method has been evaluated and validated for the determination of cefoselis sulfate in stability studies [19].

\section{Kinetic studies}

The degradation of cefoselis sulfate in aqueous solutions was examined at $353 \mathrm{~K}$ in hydrochloric acid ( $\mathrm{pH} 0.44-1.39$ ), phosphate buffer ( $\mathrm{pH} 1.89-3.10$ and 6.16-7.60), acetate buffer ( $\mathrm{pH} 4.01-5.65)$ and borate buffer $(\mathrm{pH} 8.01-9.67)$. The degradation of cefoselis sulfate in aqueous solutions of sodium hydroxide $(\mathrm{pH} 11.24-13.00)$ was examined at 298, 303, 308 and $313 \mathrm{~K}$ and the obtained results were extrapolated to $353 \mathrm{~K}$. The $\mathrm{pH}$ values of the reaction solutions and those of the buffer used to calibrate the $\mathrm{pH}$-meter were measured at reaction temperature. The $\mathrm{pH}$ values of the reaction solutions in $\mathrm{HCl}$ were calculated from the equation $\mathrm{pH}=-\log \cdot \mathrm{a}_{\mathrm{HCl}}[\mathrm{HCl}]$. The activity coefficients $\mathrm{a}_{\mathrm{HCl}}$ were obtained from the literature or calculated by interpolation of literature data [20]. The buffers were prepared according to European Pharmacopoeia 7th Edition. The $\mathrm{pH}$ values of buffers were calculated using average $\mathrm{pH}$ value of different concentration buffers. The ionic strength of solutions was adjusted to $0.5 \mathrm{~mol} \mathrm{~L}^{-1}$ using the solution of sodium chloride $\left(4 \mathrm{~mol} \mathrm{~L}^{-1}\right)$. All solutions of cefoselis sulfate were protected from light. Degradation was started by dissolving an accurately weighed sample of cefoselis sulfate $(2.5 \mathrm{mg})$ in $12.5 \mathrm{~mL}$ of reaction solution heated to the required temperature in stoppered flasks. At specified time intervals, which were determined by the rate of degradation, samples of the reaction solutions $(0.5 \mathrm{~mL})$ were collected. Then they were neutralized if necessary and instantly cooled in the mixture of ice and water. $50 \mu \mathrm{L}$ samples of the solutions were injected into the column.

\section{Results and discussion}

The HPLC method with UV detection used in this study was found suitable for the determination of cefoselis sulfate under the stress conditions of hydrolysis (acid and base), oxidation, photolysis and thermal degradation [19]. The selectivity of this method for the determination of cefoselis sulfate in the presence of degradation products was confirmed. The symmetrical peak of cefoselis sulfate $\left(t_{R}=14.58 \mathrm{~min}\right)$ was clearly separated from the peaks of the degradation products formed in the whole $\mathrm{pH}$ range (Fig. 2).

The degradation of cefoselis sulfate was a pseudo-first order reaction described by the following equation:

$$
\ln \mathrm{c}_{\mathrm{t}}=\ln \mathrm{c}_{0}-\mathrm{k}_{\mathrm{obs}} \cdot \mathrm{t}
$$

where $c_{t}$ and $c_{0}$ are the time-dependent concentration and the initial concentration of cefoselis sulfate, at time $\mathrm{t}>0$ and $\mathrm{t}=0$, respectively, $\mathrm{k}_{\mathrm{obs}}$ is the observed rate 


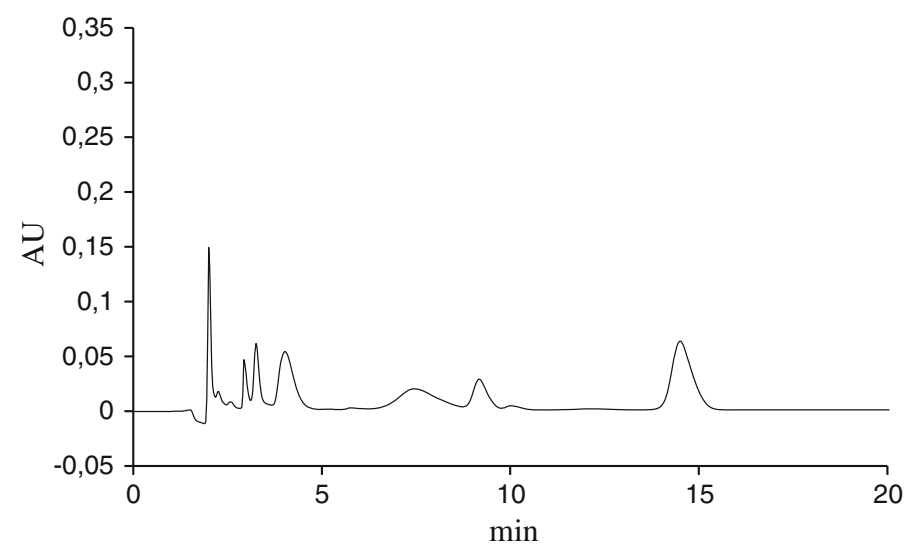

Fig. 2 HPLC chromatogram of cefoselis sulfate (retention time $14.58 \mathrm{~min}$ ) in the presence of degradation products (retention time from 1.95 to $9.97 \mathrm{~min}$ ) following incubation $7.5 \mathrm{~min}$ at borate buffer (pH 8.10) at $353 \mathrm{~K}$

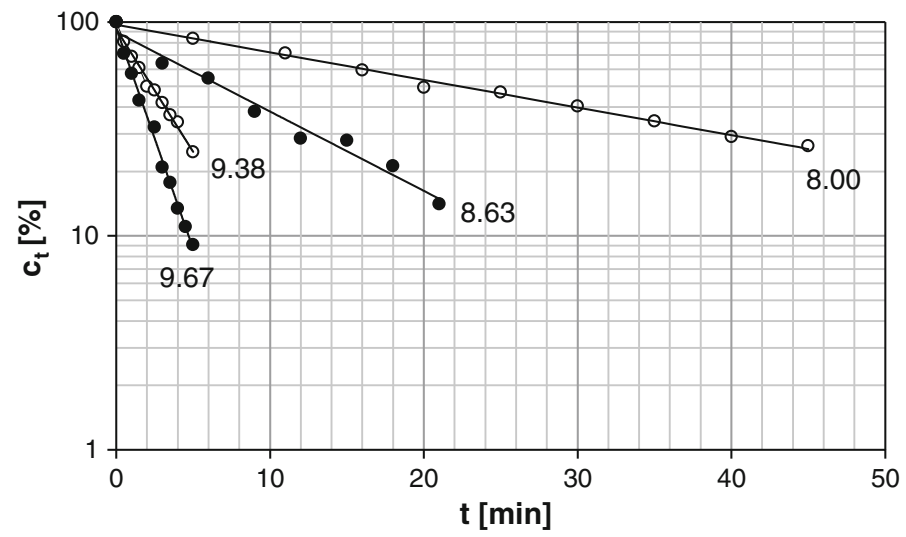

Fig. 3 Semilogarithmic plot of $c_{t}=f(t)$ for the degradation of cefoselis sulfate in borate buffers (pH 8.00-9.67) at $353 \mathrm{~K}$

constant of cefoselis sulfate degradation. The semi-logarithmic plots $\ln$ $c_{t}=f(t)$ (Fig. 3) were linear and their slopes were equal to the rate constants of the reactions with the negative sign $\left(-\mathrm{k}_{\mathrm{obs}}\right)$. The number of measurements of $\mathrm{c}_{\mathrm{t}}$ for each series ranged from 8 to 12 . The observed rate constants of cefoselis sulfate were determined in the $\mathrm{pH}$ range $0.44-13.00$.

Buffer catalysis

The fact that at a constant $\mathrm{pH}$, ionic strength and temperature, in the presence of buffer excess, the observed rate constants depended on the total concentration of buffer demonstrated only general acid-base catalysis occurred, which was observed 
in the case of the acetate $(\mathrm{pH} 4.01-5.65)$ and phosphate $(\mathrm{pH} 1.89-3.10$ and 6.167.61 ) buffers. The first order rate constants $\mathrm{k}_{\mathrm{pH}}$ under the conditions of general acidbase catalysis were calculated from the following equation:

$$
\mathrm{k}_{\mathrm{obs}}=\mathrm{k}_{\mathrm{pH}}+\mathrm{k}_{\mathrm{B}}\left[\mathrm{B}_{\mathrm{T}}\right] \text {, }
$$

where $\mathrm{k}_{\mathrm{pH}}$ is the rate constant at zero buffer concentration, $\mathrm{k}_{\mathrm{B}}$ is the catalytic effect of the buffer, $\left[\mathrm{B}_{\mathrm{T}}\right]$ is the total buffer concentration.

The plots $\mathrm{k}_{\mathrm{obs}}=\mathrm{f}\left(\left[\mathrm{B}_{\mathrm{T}}\right]\right.$ ) obtained for the acetate (Fig. 4) and phosphate (Fig. 5) buffers were linear and their slopes equaled $k_{\mathrm{B}}$ whereas the values of $\mathrm{k}_{\mathrm{obs}}$ for $\left[\mathrm{B}_{\mathrm{T}}\right]=0$ equaled $\mathrm{k}_{\mathrm{pH}}$.

The catalytic effect of the acetate buffer was investigated at $\mathrm{pH} 4.01-5.65$. The observed rate constants were calculated from the equation:

$$
\mathrm{k}_{\mathrm{obs}}=\mathrm{k}_{\mathrm{pH}}+\mathrm{k}_{\mathrm{AcH}}[\mathrm{AcH}]+\mathrm{k}_{\mathrm{AC}}-\left[\mathrm{Ac}^{-}\right]
$$

where $\mathrm{AcH}$ is the undissociated acetic acid and $\mathrm{Ac}$ is the acetate ion. The total acetate concentration $\mathrm{B}_{\mathrm{T}}$, is:

$$
\mathrm{B}_{\mathrm{T}}=[\mathrm{AcH}]+\left[\mathrm{Ac}^{-}\right]
$$

The observed rate constant was calculated from the $\mathrm{pK}_{\mathrm{a}}$ of the acetic acid (4.52) and Eqs. 2 and 3.

$$
\mathrm{k}_{\mathrm{obs}}=\mathrm{k}_{\mathrm{pH}}+\mathrm{B}_{\mathrm{T}} \frac{\mathrm{k}_{\mathrm{AcH}}\left[\mathrm{H}^{+}\right]+\mathrm{k}_{\mathrm{AC}^{-}} \mathrm{K}_{\mathrm{a}}}{\left[\mathrm{H}^{+}\right]+\mathrm{K}_{\mathrm{a}}}
$$

From the slopes of the plots, $\mathrm{k}_{\mathrm{obs}}=\mathrm{f}\left(\mathrm{B}_{\mathrm{T}}\right)$ for each $\mathrm{pH}$, the buffer catalytic rate constants were calculated. The buffer catalytic effect of the phosphate buffer $(\mathrm{pH}$ 1.89-3.10, $\mathrm{pK}_{\mathrm{a}}=2.10$ and $\mathrm{pH} 6.16-7.61, \mathrm{pK}_{\mathrm{a}}=6.58$ ) was calculated thus:

$$
\mathrm{k}_{\mathrm{obs}}=\mathrm{k}_{\mathrm{pH}}+\mathrm{B}_{\mathrm{T}} \frac{\mathrm{k}_{\mathrm{H}_{3} \mathrm{PO}_{4}}\left[\mathrm{H}^{+}\right]+\mathrm{k}_{\mathrm{H}_{2} \mathrm{PO}_{4}^{-}} \mathrm{K}_{\mathrm{a}}}{\left[\mathrm{H}^{+}\right]+\mathrm{K}_{\mathrm{a}}}
$$

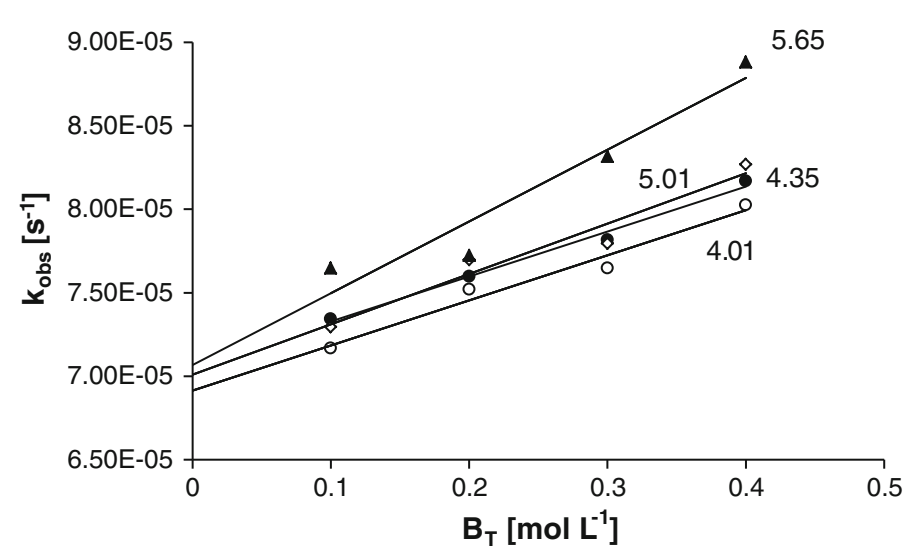

Fig. 4 Plot of $\mathrm{k}_{\mathrm{obs}}=\mathrm{f}\left(\mathrm{B}_{\mathrm{T}}\right)$ for the degradation of cefoselis sulfate in acetate buffers $(\mathrm{pH} 4.01-5.65)$ at $353 \mathrm{~K}$ 


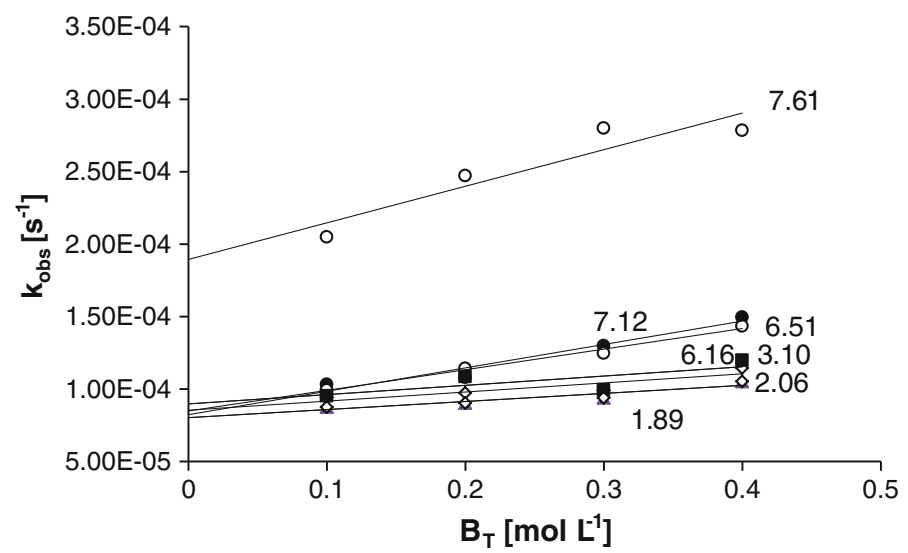

Fig. 5 Plot of $k_{o b s}=f\left(B_{T}\right)$ for the degradation of cefoselis sulfate in phosphate buffers (pH 1.89-3.10 and $6.16-7.61)$ at $353 \mathrm{~K}$

Table 1 Catalytic effect of buffers on the degradation of cefoselis sulfate

\begin{tabular}{|c|c|c|}
\hline $\begin{array}{l}\text { Phosphate buffer } \\
(\mathrm{pH} 1.89-3.10)\end{array}$ & 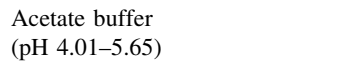 & $\begin{array}{l}\text { Phosphate buffer } \\
\text { (pH 6.16-7.61) }\end{array}$ \\
\hline $\mathrm{k}_{\mathrm{H}_{3} \mathrm{PO}_{4}}=8.06 \times 10^{-5} \mathrm{~L} \mathrm{~mol}^{-1} \mathrm{~s}^{-1}$ & $\mathrm{k}_{\mathrm{AcH}}=8.28 \times 10^{-5} \mathrm{~L} \mathrm{~mol}^{-1} \mathrm{~s}^{-1}$ & $\mathrm{k}_{\mathrm{H}_{2} \mathrm{PO}_{4}^{-}}=1.99 \times 10^{-5} \mathrm{~L} \mathrm{~mol}^{-1} \mathrm{~s}^{-1}$ \\
\hline $\mathrm{k}_{\mathrm{H}_{2} \mathrm{PO}_{4}^{-}}=8.68 \times 10^{-5} \mathrm{~L} \mathrm{~mol}^{-1} \mathrm{~s}^{-1}$ & $\mathrm{k}_{\mathrm{AC}}=3.71 \times 10^{-5} \mathrm{~L} \mathrm{~mol}^{-1} \mathrm{~s}^{-1}$ & $\mathrm{k}_{\mathrm{H}_{2} \mathrm{PO}_{4}^{2-}}=1.72 \times 10^{-4} \mathrm{~L} \mathrm{~mol}^{-1} \mathrm{~s}^{-1}$ \\
\hline
\end{tabular}

$$
\mathrm{k}_{\mathrm{obs}}=\mathrm{k}_{\mathrm{pH}}+\mathrm{B}_{\mathrm{T}} \frac{\mathrm{k}_{\mathrm{H}_{2} \mathrm{PO}_{4}^{-}}\left[\mathrm{H}^{+}\right]+\mathrm{k}_{\mathrm{HPO}_{4}^{2}} \mathrm{~K}_{\mathrm{a}}}{\left[\mathrm{H}^{+}\right]+\mathrm{K}_{\mathrm{a}}}
$$

From Eqs. 6, $7 \mathrm{k}_{\mathrm{pH}}$ and the buffer catalytic rate constants of the acetate and phosphate buffer components were calculated (Table 1).

In the reaction solutions in $\mathrm{HCl}$, borate buffer and $\mathrm{NaOH}$, general acid-base catalysis was not observed, therefore the values of $\mathrm{k}_{\mathrm{obs}}$ were equal to $\mathrm{k}_{\mathrm{pH}}$. To verify that the differences between $\mathrm{k}_{\mathrm{obs}}$ values determined at different buffer concentrations were statistically insignificant, the parallelism test was used.

pH-rate profile

The values of $\mathrm{k}_{\mathrm{pH}}$ determined in hydrochloric acid, sodium hydroxide, phosphate, borate and acetate buffers were used to calculate the relationship $\log \mathrm{k}_{\mathrm{pH}}=\mathrm{f}(\mathrm{pH})$ (Fig. 6). The semilogarithmic relationship $\mathrm{k}_{\mathrm{pH}} \mathrm{pH}$ indicates that in aqueous solutions ( $\mathrm{pH}$ 0.44-13.00) the following reactions are possible:

- degradation of a protonated cefoselis sulfate molecule $\left(\mathrm{k}_{1}\right)$

- degradation of cefoselis sulfate zwitter ions $\left(k_{2}\right)$

- degradation of cefoselis sulfate monoanions $\left(\mathrm{k}_{3}\right)$

under the influence of water. 


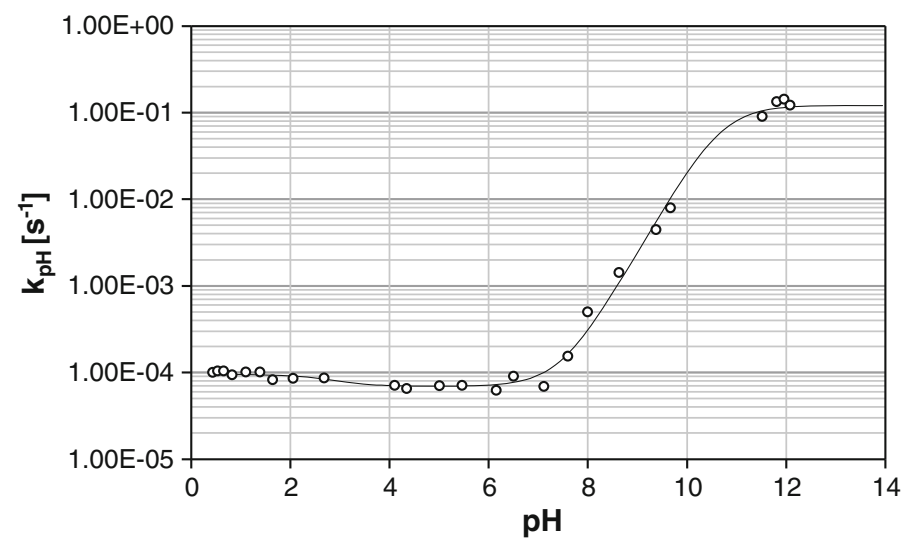

Fig. $6 \log \mathrm{k}_{\mathrm{pH}}=\mathrm{f}(\mathrm{pH})$ profile for the degradation of cefoselis sulfate at $353 \mathrm{~K}$. The points are determined experimentally and the lines were calculated from Eq. 8

The total reaction rate is equal to the sum of partial reaction rates:

$$
\mathrm{k}_{\mathrm{pH}}=\mathrm{k}_{1} \cdot \mathrm{F}_{1}+\mathrm{k}_{2} \cdot \mathrm{F}_{2}+\mathrm{k}_{3} \cdot \mathrm{F}_{3}
$$

where $F_{1}, F_{2} F_{3}$-the molar concentration fractions of cefoselis sulfate. The values $\mathrm{F}_{1-3}$ were calculated from the $\mathrm{pK}_{\mathrm{a}}$ values of cefoselis sulfate (2.8 and 10.4). The catalytic rate constants $\mathrm{k}_{1-3}$ were calculated as the mean values of $\mathrm{k}_{\mathrm{pH}}$ at $\mathrm{pH}$ 1.89-3.10, 4.01-6.16 and at $\mathrm{pH}$ above 11.24.

The correctness of Eq. 8 was verified by a good agreement between the theoretical profile calculated from Eq. 8 and the experimental results (Fig. 6).

The influence of ionic strength

The ionic strength in hydrochloric acid and in sodium hydroxide solution did not affect the stability of cefoselis sulfate, which confirmed that only spontaneous hydrolysis of cefoselis sulfate took place.

\section{Conclusion}

In aqueous solutions, in the $\mathrm{pH}$ range $0.44-13.00$, the degradation of cefoselis sulfate is a pseudo-first order reaction. The hydrolysis of the protonated molecules, zwitter ions and monoanions of cefoselis sulfate constitutes the total reaction of hydrolysis. A catalytic effect was observed in the phosphate (pH 1.89-3.10 and 6.16-7.61) and acetate ( $\mathrm{pH} 4.01-5.65)$ buffers. Cefoselis sulfate was the most stable at $\mathrm{pH} 4.0-6.5$ and the least stable above $\mathrm{pH} 11.24$.

The relationship $\log \mathrm{k}_{\mathrm{pH}}=\mathrm{f}(\mathrm{pH})$ of cefoselis sulfate indicates that it is more stable in acidic than in alkaline media and that it is characterized by a wide plateau region at acidic and neutral $\mathrm{pH}$, which confirms the influence of the 3-non-acetoxy group at position 3 (Fig. 1) on the stability of this cephalosporin. 
The catalytic effect of phosphate and acetate buffer components on the degradation of cefoselis sulfate is significant and does not depend on the buffer type, whereas the components of a borate buffer do not catalyze the degradation of cefoselis sulfate. The stability of cefoselis sulfate in the presence of a borate buffer is lower than when phosphate or acetate buffers are used, despite their catalytic effect. Therefore, the components of acetate, borate and phosphate buffers are to be avoided as excipients in pharmaceutical formulations of cefoselis sulfate.

Acknowledgments This study was supported by a Grant from the State Committee for Scientific Research, Poland (No. NN405 683040).

Open Access This article is distributed under the terms of the Creative Commons Attribution License which permits any use, distribution, and reproduction in any medium, provided the original author(s) and the source are credited.

\section{References}

1. Akaho E, Nakayama H (2003) J Antibiot (Tokyo) 56(4):379-391

2. Flessner T, Jautelat R, Scholz U, Winterfeldt E (2004) Fortschr Chem Org Naturst 87:1-80

3. Hwu JR, Ethiraj KS, Hakimelahi GH (2003) Mini Rev Med Chem 3(4):305-313

4. Patel G, Rajput S (2011) Acta Chromatogr 23(2):215-234

5. Ikeda Y, Ban J, Ishikawa T, Hashiguchi S, Urayama S, Horibe H (2008) Chem Pharm Bull 56(10):1406-1411

6. Jelińska A, Dobrowolski L, Oszczapowicz I (2004) J Pharm Biomed Anal 35(5):1273-1277

7. Sugioka T, Asano T, Chikaraishi Y, Suzuki E, Sano A, Kuriki T, Shirotsuka M, Saito K (1990) Chem Pharm Bull 38(7):1998-2002

8. Fubara JO, Notari RE (1998) J Pharm Sci 87(12):1572-1576

9. Medenecka B, Jelińska A, Zając M, Bałdyka M, Juszkiewicz K, Oszczapowicz II (2009) Acta Pol Pharm 66(5):563-569

10. Jelińska A, Medenecka B, Zając M, Knajsiak M (2008) Acta Pol Pharm 65(2):261-265

11. Zając M, Jelińska A, Zalewski P (2005) Acta Pol Pharm 62(2):89-94

12. Jelińska A, Dudzińska I, Zając M, Oszczapowicz I, Krzewski W (2005) Acta Pol Pharm 62(3):183-187

13. Zając M, Jelińska A, Dobrowolski L, Oszczapowicz I (2003) J Pharm Biomed Anal 32(6):1181-1187

14. Jelińska A, Zając M, Gostomska J, Szczepaniak M (2003) Farmaco 58(4):309-313

15. Jelińska A, Zając M, Jakubowska M (2001) React Kinet Catal Lett 73(2):325-331

16. Kuriyama T, Karasawa T, Nakagawa K, Nakamura S, Yamamoto E (2002) Oral Microbiol Immunol 17(5):285-289

17. Climo MW, Markowitz SM, Williams DS, Hale-Cooper CG, Archer GL (1997) J Antimicrob Chemother 40(1):59-66

18. Zalewski P, Cielecka-Piontek J (2011) Ann Acad Med Siles 65(3):77-81

19. Zalewski P, Cielecka-Piontek J, Jelińska A (2012) Cent Eur J Chem 10(1):121-126

20. Pawełczyk E, Hermann T (1982) The fundamentals of stability drugs (Poland). PZWL, Warsaw 